\title{
ANALISIS DAN PERANCANGAN SISTEM INFORMASI PENJUALAN TUNAI, PENGELOLAAN PERSEDIAAN BAHAN BAKU, DAN PRODUKSI PADA CV $X$
}

\author{
Vega Ariena \\ Yenita Juandy \\ Sekolah Tinggi Manajemen Informatika dan Komputer LIKMI \\ Jl. Ir. H. Juanda 96 Bandung 40132
}

\begin{abstract}
ABSTRAK
Pengaruh teknologi memasuki hampir seluruh aspek kehidupan manusia dan juga perekonomian guna menunjang proses bisnis menjadi lebih efektif dan efisien. Sistem informasi yang berjalan di CV X saat ini masih belum berjalan dengan baik, belum memanfaatkan komputer sehingga waktu pengerjaan tugas terhambat dan keakuratan data tidak terjamin, proses pencarian data menjadi lebih lama.

Penulis merancang sistem informasi baru yang lebih akurat, mudah digunakan, dan sesuai dengan pekerjaan masing-masing pengguna sistem informasi. Selain itu sistem informasi yang sudah dirancang dilengkapi dengan pengamanan sistem untuk menghindari ancaman pasif dan aktif yang mungkin terjadi seperti sabotase, pencurian data, hilangnya data akibat bencana alam maupun tindakan-tindakan yang tidak disengaja. Pengendalian internal pun menjadi hal penting yang harus diperhatikan oleh perusahaan untuk dapat menjalankan proses bisnisnya dengan baik.
\end{abstract}

Kata-kata kunci : sistem informasi, pengendalian internal

\section{PENDAHULUAN}

Banyak perusahaan sudah memanfaatkan teknologi dan informasi (komputer) dalam berbagai aktivitas perusahaannya untuk mempermudah pekerjaan karyawannya, data lebih akurat, informasi cepat tersaji, dan sebagainya. CV X merupakan sebuah perusahaan yang bergerak di bidang percetakan, dimana pencatatan data masih dilakukan secara manual, sehingga menimbulkan berbagai masalah, yaitu:

a. Terjadinya ketidakakuratan pada data penjualan tunai, persediaan bahan baku, dan produksi dengan data yang ada di lapangan.

b. Terhambatnya waktu penyelesaian proyek.

c. Proses produksi kurang diawasi sehingga terjadi kesalahan dalam produksi.

d. Kesalahan pada saat pengiriman barang kepada pelangganakibat pencatatan yang kurang lengkap.

Penelitian ini dibatasi pada masalah sebagai berikut:

a. Transaksi penjualan tunai yang terjadi di CV Karunia Bhakti.

b. Proses produksi barang mulai dari bahan baku hingga menjadi barang jadi.

c. Pencatatan persediaan bahan baku yang terpakai.

\section{LANDASAN TEORI}

Menurut Azhar Susanto dalam bukunya yang berjudul "Sistem Informasi Akuntansi" adalah sebagai berikut:

"Sistem adalah kumpulan atau grup dari sub sistem atau komponen apapun baik fisik ataupun non fisik yang saling berhubungan satu sama lain dan bekerja sama secara harmonis untuk mencapai satu tujuan tertentu." (Susanto, 2013:22) 
Menurut McLeod dikutip oleh Yakub pada buku "Pengertian Sistem Informasi", pengertian informasi adalah sebagai berikut:

"Informasi adalah data yang diolah menjadi bentuk lebih berguna dan lebih berarti bagi yang menerimanya." (Yakub, 2012:8)

Menurut Romney dan Steinbart sistem informasi akuntansi adalah:

Sistem yang digunakan untuk mengumpulkan, mencatat, menyimpan dan mengolah data untuk menghasilkan suatu informasi untuk pengambilan keputusan. Sistem ini meliputi orang, prosedur dan instruksi data perangkat lunak, infrastruktur teknologi informasi serta pengendalian internal dan ukuran keamanan. (Romney, 2015:10)

Ada tiga fungsi sistem informasi akuntansi menurut Azhar Susanto dalam bukunya yang berjudul Sistem Informasi Akuntansi (Susanto, 2013:8) yaitu sebagai berikut:

a. Mendukung aktivitas perusahaan sehari-hari.

b. Mendukung proses pengambilan keputusan.

c. Membantu pengelola perusahaan dalam memenuhi tanggung jawabnya kepada pihak eksternal.

Menurut Julianto Agung Saputra dan Lilis Setiawat dalam bukunya yang berjudul "Sistem Informasi Akuntansi Edisi 9" ada beberapa teknik input kontrol sebagai berikut (Saputra, 2006:249):

a. Completeness check(memastikan field yang harus diisi memang telah diisi)

b. Field format check (pengecekan setiap karakter memiliki tipe data yang benar)

c. Field length check (pengecekan data apakah memilki jumlah karakter tertentu)

d. Field sign check(pengecekan tanda positif atau negatif suatu field)

e. Limit check (nilai suatu field numerik dibandingkan dengan batas atas dan batas bawah nilai yang telah ditentukan)

f. Valid code check(mencocokkan nilai suatu kode dengan field tabel)

g. Check digit(validasi kode numerik dengan penggunaan algoritma check digit)

h. Prenumbered(penomoran yang dilakukan secara otomatis)

i. Sequence check(sebuah field didalam serangkaian record dicek urutannya)

\section{PEMBAHASAN}

Prosedur-prosedur kerja yang berjalan pada CV X dijelaskan pada Gambar 1 dan 2. 


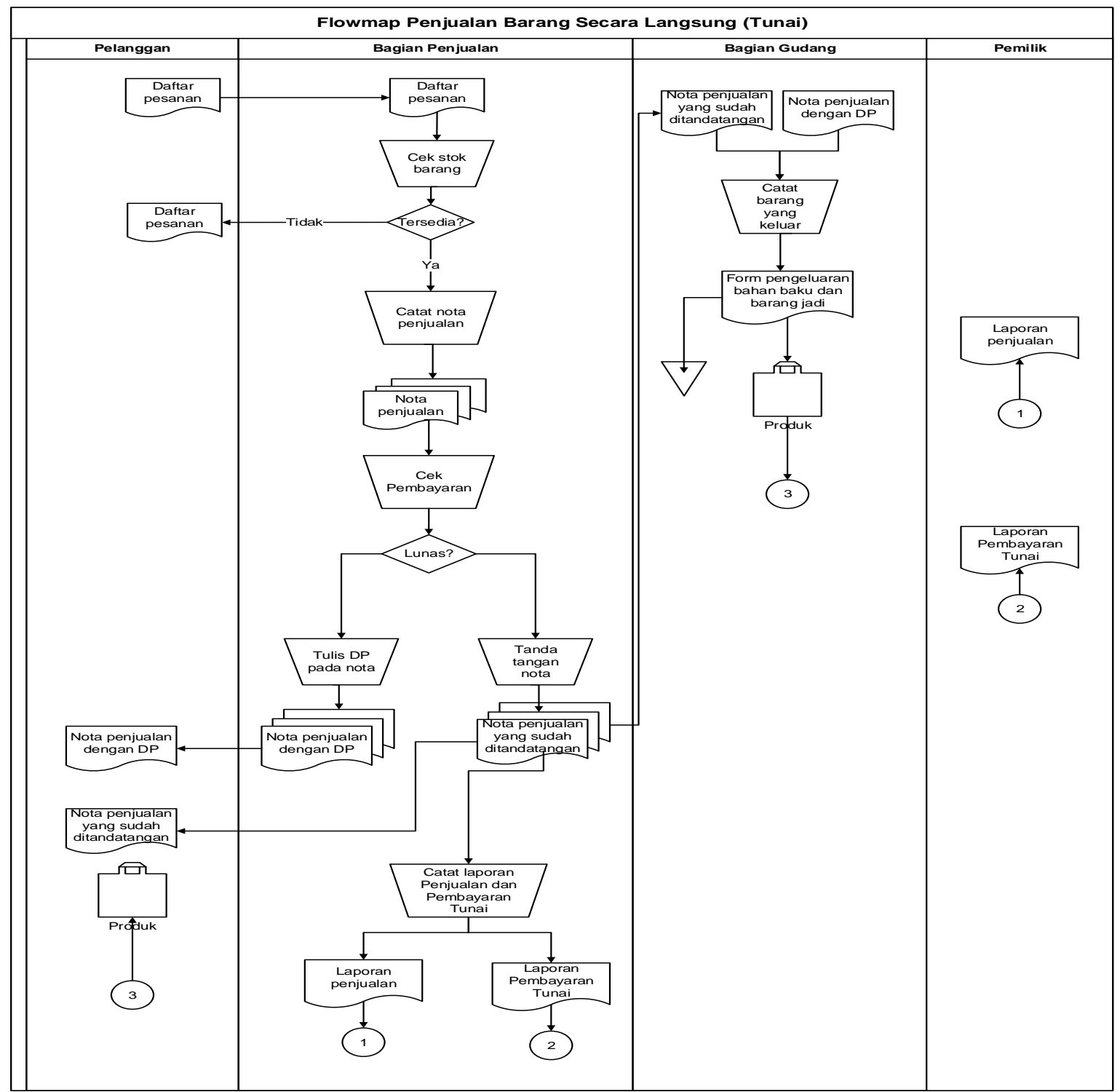

Gambarl. Flowmap Penjualan Barang Secara Langsung (Tunai) 


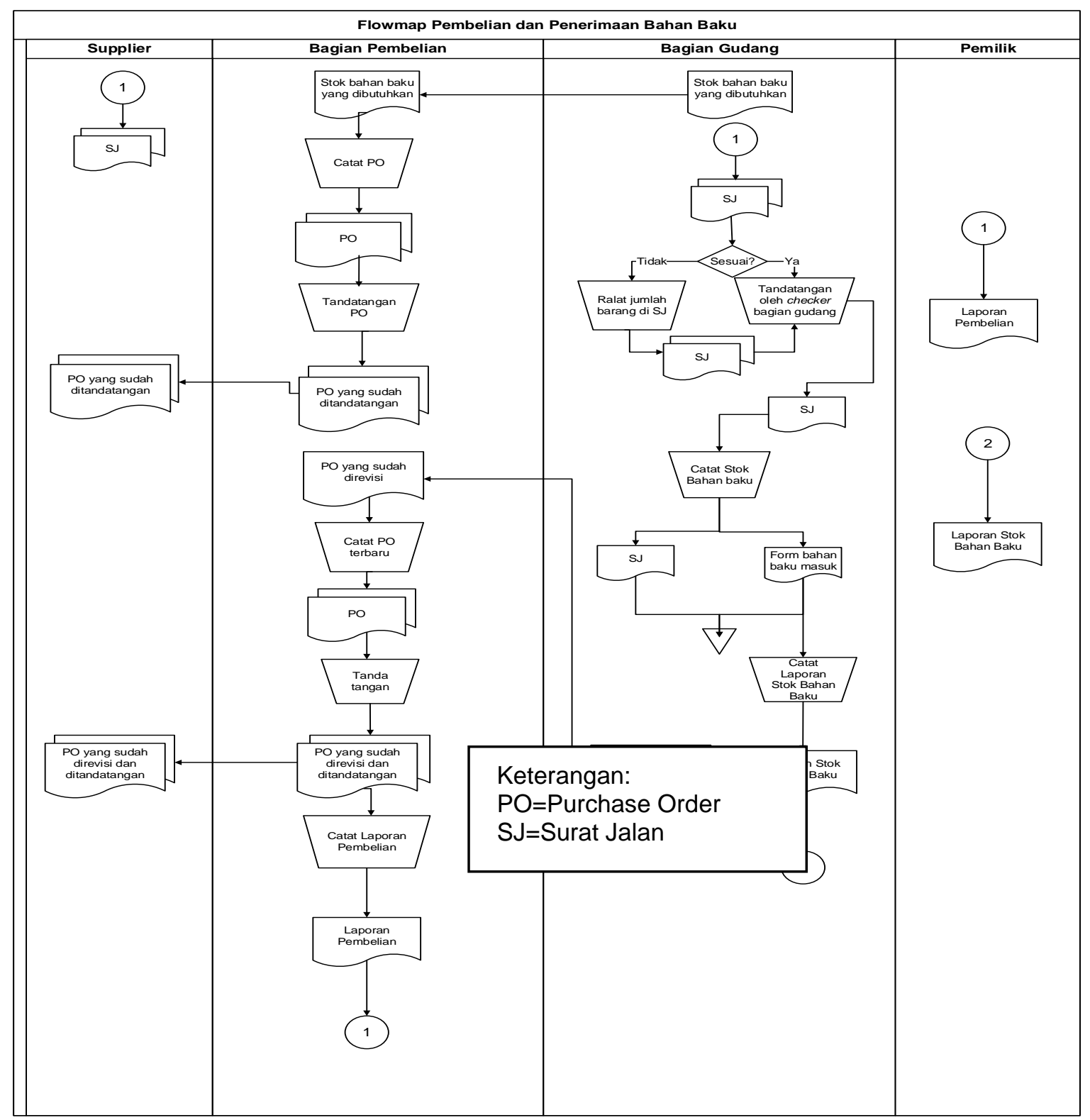

Gambar 2. Flowmap Pembelian dan Penerimaan Bahan Baku

Berdasarkan penelitian yang telah dilakukan, penulis menguraikan kekurangan sistem yang ada beserta solusinya.

Tabel 1. Evaluasi Struktur Pengendalian Internal

\begin{tabular}{|c|c|c|c|}
\hline No & $\begin{array}{l}\text { Komponen } \\
\text { Pengendalian } \\
\text { Internal }\end{array}$ & Evaluasi & Solusi \\
\hline 1. & \multicolumn{3}{|c|}{ Lingkungan Pengendalian } \\
\hline & $\begin{array}{l}\text { a. Integritas dan } \\
\text { etika }\end{array}$ & $\begin{array}{l}\text { 1. Adanya karyawan } \\
\text { yang tidak mematuhi } \\
\text { peraturan } \\
\text { 2. Tidak adanya Standar } \\
\text { Operasional Prosedur } \\
\text { (SOP) secara tertulis }\end{array}$ & $\begin{array}{l}\text { 1. Menciptakan budaya beretika } \\
\text { yang baik dan memberikan } \\
\text { teguran atau tindakan tegas } \\
\text { ketika karyawan melanggar. } \\
\text { 2. Pemilik menetapkan SOP } \\
\text { yang jelas. }\end{array}$ \\
\hline & $\begin{array}{l}\text { b. Komitmen } \\
\text { untuk }\end{array}$ & $\begin{array}{l}\text { Keahlian karyawan dalam } \\
\text { menggunakan komputer }\end{array}$ & $\begin{array}{l}\text { Mengadakan pelatihan khusus } \\
\text { komputer untuk karyawan. }\end{array}$ \\
\hline
\end{tabular}




\begin{tabular}{|c|c|c|c|}
\hline No & $\begin{array}{l}\text { Komponen } \\
\text { Pengendalian } \\
\text { Internal }\end{array}$ & Evaluasi & Solusi \\
\hline & $\begin{array}{l}\text { meningkatkan } \\
\text { kompetensi }\end{array}$ & masih rendah. & \\
\hline & $\begin{array}{ll}\text { c. } & \text { Dewan } \\
\text { komisaris dan } \\
\text { komite audit }\end{array}$ & $\begin{array}{l}\text { Pemilik jarang melakukan } \\
\text { pertemuan khusus dengan } \\
\text { karyawan untuk } \\
\text { menyelesaikan } \\
\text { permasalahan. }\end{array}$ & $\begin{array}{l}\text { Pemilik mengadakan pertemuan } \\
\text { khusus yang diadakan untuk } \\
\text { mengevaluasi dan } \\
\text { menyelesaikan permasalahan. }\end{array}$ \\
\hline & d. $\begin{array}{l}\text { Struktur } \\
\text { organisasi }\end{array}$ & $\begin{array}{l}\text { Masih adanya yang } \\
\text { merangkap jabatan. }\end{array}$ & $\begin{array}{l}\text { Menetapkan pembagian tugas } \\
\text { masing-masing. }\end{array}$ \\
\hline 2. & Penilaian Resiko & $\begin{array}{l}\text { Tidak adanya CCTV di } \\
\text { setiap ruangan sehingga } \\
\text { menyebabkan terjadinya } \\
\text { tindakan pencurian dan } \\
\text { penyelewengan lainnya. }\end{array}$ & $\begin{array}{l}\text { Pemilik memasang CCTV di } \\
\text { setiap ruangan yang dianggap } \\
\text { memiliki potensi terjadinya } \\
\text { penyelewengan. }\end{array}$ \\
\hline 3. & $\begin{array}{l}\text { Aktivitas } \\
\text { Pengendalian }\end{array}$ & $\begin{array}{l}\text { Belum adanya pemisahan } \\
\text { fungsi dengan baik di } \\
\text { perusahaan } \\
\text { memungkinkan terjadinya } \\
\text { kecurangan. }\end{array}$ & $\begin{array}{l}\text { Melakukan kontrol terhadap } \\
\text { pekerjaan yang dilakukan oleh } \\
\text { karyawan }\end{array}$ \\
\hline 4. & $\begin{array}{l}\text { Informasi dan } \\
\text { komunikasi }\end{array}$ & $\begin{array}{ll}\text { 1. } & \text { Dokumen-dokumen } \\
\text { tidak disusun rapih dan } \\
\text { mempersulit pencarian. } \\
\text { 2. Tidak adanya laporan } \\
\text { keuangan periodik oleh } \\
\text { bagian keuangan. }\end{array}$ & $\begin{array}{l}\text { 1. Menyediakan lemari khusus } \\
\text { dokumen sesuai dengan } \\
\text { bagiannya. } \\
\text { 2. Bagian keuangan membuat } \\
\text { laporan keuangan setiap } \\
\text { sebulan. }\end{array}$ \\
\hline 5. & Pemantauan & $\begin{array}{l}\text { Tidak adanya pengawasan } \\
\text { secara rutin terhadap } \\
\text { pekerjaan karyawan. }\end{array}$ & $\begin{array}{l}\text { Pemilik memantau pekerjaan } \\
\text { karyawan secara rutin. }\end{array}$ \\
\hline
\end{tabular}

Evaluasi dan solusi yang penulis rancang untuk prosedur penjualan tunai, persediaan bahan baku, dan produksi digambarkan pada Tabel 2 .

Tabel 2. Evaluasi Prosedur Sistem Informasi

\begin{tabular}{|c|c|c|c|}
\hline No & Prosedur & Evaluasi & Solusi \\
\hline 1. & Penjualan & $\begin{array}{l}\text { 1. Pencatatan penjualan } \\
\text { dilakukan manual. } \\
\text { 2. Tidak adanya surat jalan } \\
\text { untuk pengiriman } \\
\text { barang. }\end{array}$ & $\begin{array}{l}\text { 1. Transaksi penjualan dicatat } \\
\text { ke komputer. } \\
\text { 2. Bagian penjualan membuat } \\
\text { surat jalan. }\end{array}$ \\
\hline 2. & $\begin{array}{l}\text { Pengelolaan } \\
\text { bahan baku }\end{array}$ & & \\
\hline & $\begin{array}{l}\text { a. Pembelian } \\
\text { bahan baku }\end{array}$ & $\begin{array}{l}\text { Bahan baku terlambat } \\
\text { dipesan }\end{array}$ & $\begin{array}{l}\text { Pencatatan stok bahan baku } \\
\text { dilakukan secara rutin. }\end{array}$ \\
\hline & $\begin{array}{l}\text { b. Penerimaan } \\
\text { bahan baku }\end{array}$ & $\begin{array}{l}\text { Catatan bahan baku yang } \\
\text { diterima oleh bagian } \\
\text { gudang tidak diarsipkan } \\
\text { secara rapih dan tersusun. }\end{array}$ & $\begin{array}{l}\text { Semua catatan penerimaan } \\
\text { bahan baku disimpan dengan } \\
\text { baik. }\end{array}$ \\
\hline
\end{tabular}




\begin{tabular}{|c|c|c|c|}
\hline No & Prosedur & Evaluasi & Solusi \\
\hline 3. & Produksi & $\begin{array}{l}\text { 1. Standar keamanan dan } \\
\text { pengawasan dari } \\
\text { pemilik masih kurang. } \\
\text { 2. Bagian produksi jarang } \\
\text { menyimpan stok barang } \\
\text { jadi. }\end{array}$ & $\begin{array}{l}\text { 1. Pemilik menetapkan standar } \\
\text { keamanan pada saat } \\
\text { produksi dan melakukan } \\
\text { pengawasan produksi. } \\
\text { 2. Bagian produksi } \\
\text { memproduksi barang untuk } \\
\text { stok. }\end{array}$ \\
\hline
\end{tabular}

Hasil perancangan sistem baru digambarkan berupa Diagram Aliran Data (DAD) Level 0 pada Gambar 3.

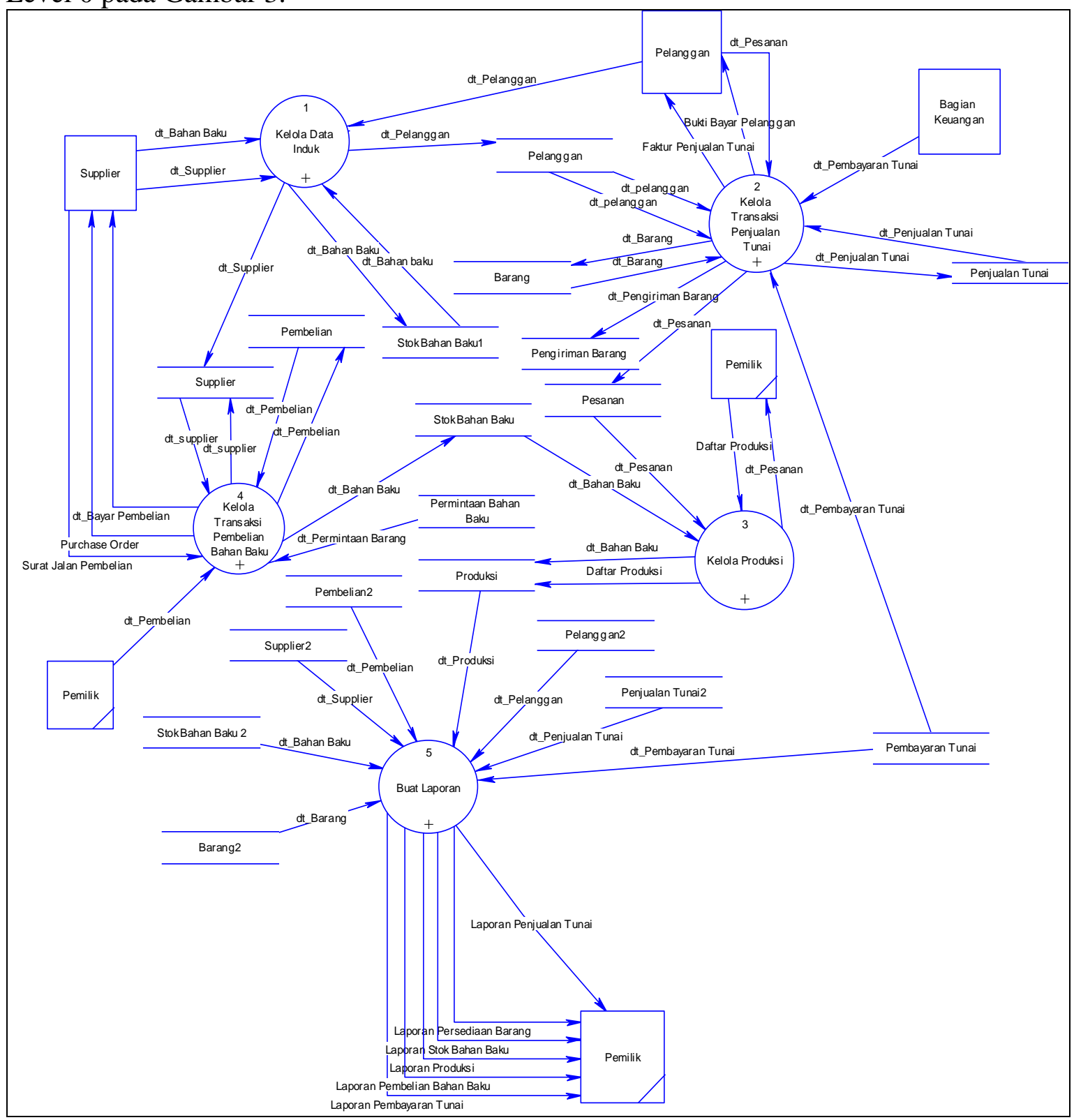

Gambar 3. DAD Level 0

Sedangkan desain basisdata ditampilkan berupa Entity Relationship Diagram (ERD) dan model keterhubungan antar tabel pada Gambar 4 dan Gambar 5. 


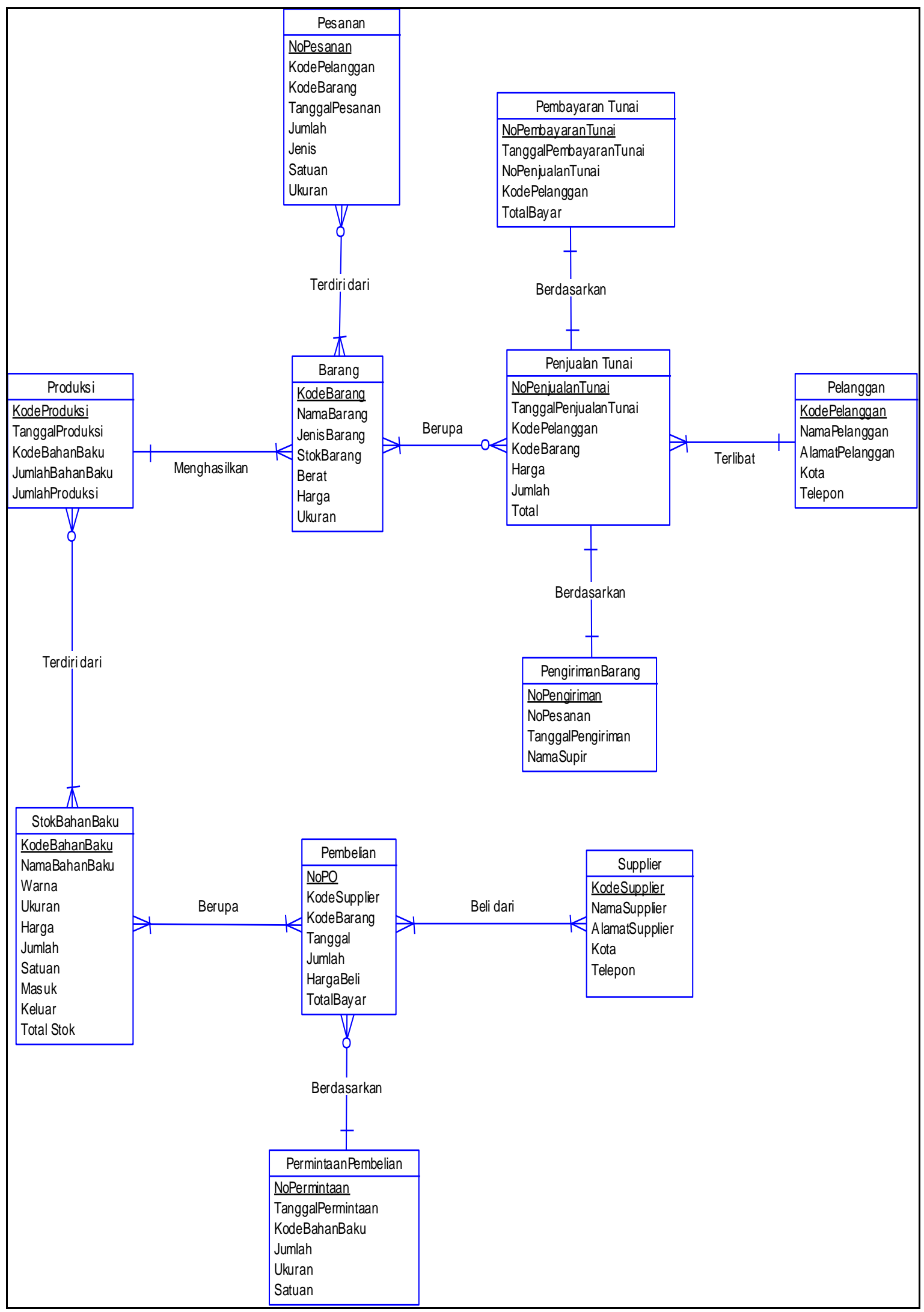

Gambar 4. Entity Relationship Disagram 


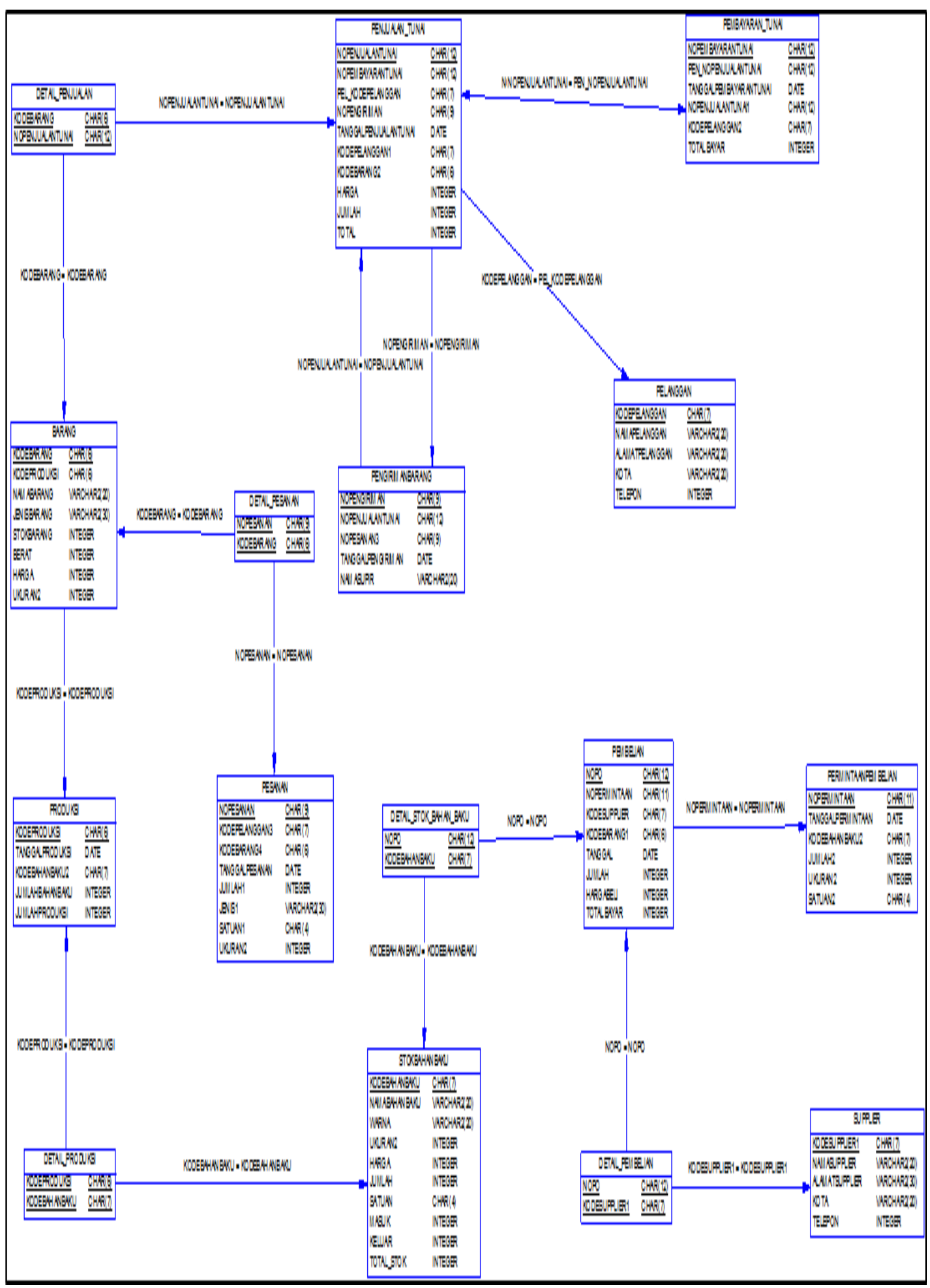

Gambar 5. Model Keterhubungan Antar Tabel

Pengendalian aplikasi adalah sistem pengendalian yang digunakan pada saat pemprosesan transaksi untuk menjamin bahwa elemen-elemen struktur pengendalian internal diimplementasikan dalam sistem aplikasi perusahaan. 
Tabel 3. Pengendalian Aplikasi Pada Form Transaksi Pembelian

\begin{tabular}{|l|l|l|}
\hline No & \multicolumn{1}{|c|}{ Nama Field } & \multicolumn{1}{c|}{ Input Control } \\
\hline 1. & Nomor PO & $\begin{array}{l}\text { Completeness check, field format check, field length } \\
\text { check. }\end{array}$ \\
\hline 2. & Kode Supplier & $\begin{array}{l}\text { Completeness check, field format check, field length } \\
\text { check. }\end{array}$ \\
\hline 3. & Kode Barang & $\begin{array}{l}\text { Completeness check, field format check, field length } \\
\text { check. }\end{array}$ \\
\hline 4. & Tanggal & Completeness check, field format check. \\
\hline 5. & Jumlah & Completeness check, field format check, field sign check. \\
\hline 6. & Harga Beli & Completeness check, field format check, field sign check. \\
\hline 7. & Total & Completeness check, field format check, field sign check. \\
\hline
\end{tabular}

Tabel 4. Pengendalian Aplikasi Pada Form Transaksi Penjualan

\begin{tabular}{|l|l|l|}
\hline No & \multicolumn{1}{|c|}{ Nama Field } & \multicolumn{1}{c|}{ Input Control } \\
\hline 1. & $\begin{array}{l}\text { Nomor Penjualan } \\
\text { Tunai }\end{array}$ & $\begin{array}{l}\text { Completeness check, field format check, field length } \\
\text { check. }\end{array}$ \\
\hline 2. & Kode Supplier & $\begin{array}{l}\text { Completeness check, field format check, field length } \\
\text { check. }\end{array}$ \\
\hline 3. & Kode Barang & $\begin{array}{l}\text { Completeness check, field format check, field length } \\
\text { check. }\end{array}$ \\
\hline 4. & $\begin{array}{l}\text { Tanggal Penjualan } \\
\text { Tunai }\end{array}$ & Completeness check, field format check. \\
\hline 5. & Harga & $\begin{array}{l}\text { Completeness check, field format check, field sign } \\
\text { check. }\end{array}$ \\
\hline 6. & Jumlah & $\begin{array}{l}\text { Completeness check, field format check, field sign } \\
\text { check. }\end{array}$ \\
\hline 7. & Total & $\begin{array}{l}\text { Completeness check, field format check, field sign } \\
\text { check. }\end{array}$ \\
\hline
\end{tabular}

Tabel 5. Pengendalian Aplikasi Pada Form Transaksi Pembayaran

\begin{tabular}{|l|l|l|}
\hline No & \multicolumn{1}{|c|}{ Nama Field } & \multicolumn{1}{c|}{ Input Control } \\
\hline 1. & Nomor Pembayaran Tunai & $\begin{array}{l}\text { Completeness check, field format check, field } \\
\text { length check. }\end{array}$ \\
\hline 2. & Nomor Penjualan Tunai & $\begin{array}{l}\text { Completeness check, field format check, field } \\
\text { length check. }\end{array}$ \\
\hline 3. & Kode Pelanggan & $\begin{array}{l}\text { Completeness check, field format check, field } \\
\text { length check. }\end{array}$ \\
\hline 4. & Tanggal Pembayaran Tunai & Completeness check, field format check. \\
\hline 5. & Total Bayar & $\begin{array}{l}\text { Completeness check, field format check, field } \\
\text { sign check. }\end{array}$ \\
\hline
\end{tabular}




\section{KESIMPULAN}

Berdasarkan hasil analisis dan penelitian yang telah dilakukan penulis maka penulis menyimpulkan beberapa hal mengenai sistem informasi penjualan tunai, pengelolaan persediaan bahan baku, sebagai berikut:

a. Dalam proses pengelolaan data penjualan tunai, pengelolaan persediaan bahan baku, dan produksi pada sistem yang lama, sering terjadi pencatatan data secara ganda dan tidak valid sehingga informasi yang dihasilkan tidak akurat dan berbeda dengan data di lapangan.. Dengan adanya perancangan program aplikasi baru, pengguna dapat dengan mudah mencatat data penjualan, produksi, dan persediaan bahan baku dengan menggunakan program aplikasi.

b. Penyelesaian tugas-tugas perusahaan dalam sistem lama seringkali terhambat karena masih adanya karyawan yang bekerja secara ganda. Dengan adanya perancangan uraian tugas yang baru, karyawan dapat bekerja sesuai dengan tugas dan bagiannya masing-masing.

c. Barang yang sudah diproduksi terdapat cacat akibat human error dan pengawasan yang kurang. Dengan adanya sistem yang baru, pengawasan dapat dilakukan lebih intensif lagi sehingga dapat mengurangi barang cacat ketika selesai diproduksi.

d. Dengan adanya sistem pencatatan pada saat penjualan yang lebih baik dan lebih tertata dalam sistem yang baru maka kesalahan pada saat mengirim barang pesanan kepada pelanggan dapat berkurang.

e. Penulis merancang sistem informasi yang mudah dimengerti dan mudah digunakan dalam proses pengelolaan data penjualan tunai, pengelolaan persediaan bahan baku, dan produksi.

\section{DAFTAR PUSTAKA}

[1] James, A. Hall. 2007. Sistem Informasi Akuntansi. Edisi Ketiga, Terjemahan Amir Abadi Yusuf. Jakarta: Salemba Empat.

[2] Jogiyanto, H.M., MBA,Ph.D., . 2010, Analisis \& Desain Sistem Informasi. Yogyakarta: Andi.

[3] Kristanto, Andi. 2008. Perancangan Sistem Informasi. Yogyakarta: Gava Media.

[4] Kristanto, Andri. 2008. Perancangan Sistem Informasi dan Aplikasinya. Yogyakarta: Gava Media.

[5] Puspitawati, Lilis., Sri Dewi Anggadini. 2011.Sistem Informasi Akuntansi. Yogyakarta: Graha Ilmu.

[6] Romney, M.B., \& Steinbart, P.J. 2012. Accounting information Systems (twelfth edition). England: Pearson.

[7] Saputra, Julianto Agung dan Lilis Setiawati. 2006. Sistem Informasi Akuntansi Edisi 9. Yogyakarta: Andi. 